\title{
PENINGKATAN KEMAMPUAN KONEKSI MATEMATIS DAN SELF- EFFICACY SISWA MELALUI MODEL PEMBELAJARAN KOOPERATIF TIPE ROTATING TRIO EXCHANGE (RTE)
}

\author{
Erna Isfayani ${ }^{1}$, Rahmah Johar ${ }^{2}$, Said Munzir ${ }^{3}$ \\ ${ }^{1,2}$ Prodi Magister Pendidikan Matematika Pascasarjana Universitas Syiah Kuala Banda Aceh \\ ${ }^{3}$ Prodi Magister Matematika Universitas Syiah Kuala Banda Aceh \\ eisfayani@ymail.com
}

\begin{abstract}
Abstrak
Penelitian ini bertujuan untuk mengetahui peningkatan kemampuan koneksi matematis dan Self efficacy siswa yang memperoleh pembelajaran dengan Model Pembelajaran Kooperatif Tipe Rotating Trio Exchange (RTE) dibandingkan siswa yang memperoleh pembelajaran matematika secara konvensional. Teknik pengumpulan data dilakukan dengan cara melakukan tes hasil belajar siswa dan angket self-efficacy siswa. Analisis data kemampuan koneksi matematis dan data self-efficacy siswa dilakukan dengan menggunakan Independent-Sample $t$ Test. Hasil pengujian hipotesis menunjukkan bahwa: (1) Peningkatan kemampuan koneksi matematis siswa yang memperoleh pembelajaran dengan model pembelajaran RTE lebih baik dibandingkan dengan kemampuan koneksi matematis siswa yang memperoleh pembelajaran konvensional; (2) Peningkatan kemampuan self-efficacy siswa yang memperoleh pembelajaran dengan model pembelajaran RTE lebih baik dibandingkan dengan kemampuan self-efficacy siswa yang memperoleh pembelajaran konvensional. Berdasarkan hasil angket self-efficacy menunjukkan bahwa siswa menunjukkan sikap positif terhadap pembelajaran matematika yang menggunakan model Pembelajaran Kooperatif Tipe RTE
\end{abstract}

Kata Kunci: Kemampuan koneksi matematis, Self- efficacy, Model pembelajaran kooperatif tipe Rotating Trio Exchange (RTE)

\begin{abstract}
This study aims to determine the improvement of mathematical connection capability and self efficacy of students who have learned by Cooperative Learning Model Type Rotating Trio Exchange (RTE) compared to students who received conventional mathematics learning. Collection technique is done by doing test result of student learning and selfefficacy questionnaire of student. Data analysis of mathematical connection capability and student self-efficacy data were performed by using Independent-Sample $t$ Test. The result of hypothesis testing shows that: (1) Improvement of mathematical connection ability of students who gain learning with RTE learning model better than mathematical connection ability of students who gain conventional learning; (2) Increased ability of self-efficacy of students who gain learning with RTE learning model better than the ability of self-efficacy of students who obtain conventional learning. Based on selfefficacy questionnaire indicated that students showed positive attitude toward mathematics learning using RTE Type Co-operative Model
\end{abstract}

Keywords: Mathematical connection ability, Self-efficacy, Rotating Trio Exchange type (RTE) cooperative learning model 


\section{PENDAHULUAN}

Karakteristik dari matematika adalah tidak terpartisi dalam berbagai topik yang saling terpisah, namun matematika merupakan satu kesatuan. Selain itu matematika juga tidak bisa terpisah dari ilmu selain matematika dan masalah-masalah yang terjadi dalam kehidupan. Untuk memahami proses keterkaitankan ini, maka diperlukan kemampuan koneksi matematis. Tanpa koneksi matematis maka siswa harus belajar dan mengingat terlalu banyak konsep dan prosedur matematika yang saling terpisah (NCTM, 2000). Konsep-konsep dalam bilangan pecahan, presentase, rasio, dan perbandingan linear merupakan salah satu contoh topik-topik yang dapat dikaitkan.

Kemampuan koneksi matematis merupakan kemampuan siswa untuk mengaitkan peristiwa/kejadian dalam kehidupan sehari-hari dengan materi pelajaran (keterkaitan konteks eksternal) dan mengkaitkan antar konsep dalam matematika itu sendiri (keterkaitan konteks internal). Indikator untuk mengukur kemampuan matematis, yaitu : mengenali dan memanfaatkan hubungan-hubungan antara gagasan dalam matematika untuk menghasilkan suatu keutuhan koheren, dan mengenali serta menerapkan matematika dalam konteks-konteks di luar matematika (NCTM, 2000). Keterkaitan dalam konteks eksternal maupun internal membuat pembelajaran menjadi lebih bermakna karena siswa dapat melihat masalah yang nyata dalam pembelajaran serta mampu menyelesaikan masalah tersebut sesuai dengan konsep-konsep matematis di dalamnya.

Kemampuan koneksi matematika perlu dilatihkan kepada siswa di sekolah. Apabila siswa mampu mengkaitkan ide-ide matematika maka koneksi matematikanya akan semakin dalam dan bertahan lama karena mereka mampu melihat keterkaitan antar topik dalam matematika, dengan konteks selain matematika, dan dengan pengalaman hidup sehari-hari (NCTM, 2000).

Selain dari aspek kognitif, dalam diri siswa juga ada aspek psikologi, salah satunya adalah self-efficacy. Menurut Bandura (1997) yang menyatakan bahwa self-efficacy merupakan penilaian diri terhadap kemampuan seseorang untuk mengatur dan melaksanakan rangkaian tindakan untuk mencapai tujuan yang diharapkan, mampu mengukur kemampuan diri dalam melakukan berbagai tindakan sesuai tingkatan, keumuman dan kekuatan dalam berbagai situasi/keadaan. Self-efficacy pada siswa adalah penilaian atas kemampuan diri siswa dalam mengatur dan melaksanakan berbagai macam tugas-tugas akademik yang diberikan oleh guru. Self-efficacy mempengaruhi pilihan tindakan yang akan dilakukan dan besarnya 
usaha ketika menemui kesulitan dan hambatan. Individu yang memiliki self-efficacy tinggi memilih untuk melakukan usaha lebih besar dan tidak mudah putus asa.

Menurut Bandura (1997), self-efficacy mencakup tiga dimensi, yaitu: (a) Magnitude, yaitu siswa menilai keyakinan dan kemampuan dirinya sendiri dalam mengatasi berbagai kesulitan dalam penyelesaian tugas. Dalam dimensi magnitude ini, siswa dihadapkan pada variasi permasalahan matematika dengan tingkat kesulitan yang berbeda-beda. Individu yang memiliki tingkat self-efficacy yang tinggi memiliki keyakinan bahwa ia mampu mengerjakan tugas-tugas yang sulit sedangkan individu yang memiliki self-efficacy rendah memiliki keyakinan bahwa dirinya hanya mampu mengerjakan tugas yang mudah, (b) Generality (generalisasi), artinya individu menilai keyakinan diri sendiri pada berbagai kegiatan tertentu. Generalisasi memiliki perbedaan dimensi yang bervariasi meliputi: derajat kesamaan akivitas; modal kemampuan yang ditunjukkan melalui tingkah laku, kognitif, dan afektif; menggambarkan situasi secara nyata; menunjukkan karakteristik perilaku individu. Pada konteks generality ini, merupakan perasaan siswa terhadap kemampuan dirinya sendiri dalam menyelesaikan berbagai macam situasi tugas atau konteks tugas yang berbeda-beda dari guru, (c) Strength (kekuatan/ketahanan), dimensi ini merupakan ketahanan dan keuletan individu/siswa dalam pemenuhan tugasnya. Siswa yang memiliki keyakinan dan kemantapan yang kuat terhadap kemampuannya untuk menyelesaikan suatu tugas akan terus bertahan dalam usahannya meskipun banyak mengalami kesulitan dan tantangan. Jadi, dapat disimpulkan bahwa self-efficacy dalam matematika adalah keyakinan siswa atau individu terhadap kemampuannya untuk mengatur dan melaksanakan kegiatan belajar matematika untuk mencapai suatu tujuan tertentu dengan cara memprediksi seberapa besar usaha yang dibutuhkan untuk mencapai tujuan tersebut yang termuat dalam dimensi magnitude, level, dan strenght.

Keberhasilan pembelajaran matematika dapat dilihat dari prestasi belajar matematika dan aspek kemampuan lain yang mendukung prestasi tersebut. Permendiknas Nomor 20 Tahun 2007 menyatakan bahwa pencapaian hasil belajar siswa dikelompokkan ke dalam 3 ranah, yaitu kognitif (pengetahuan yang mencakup kecerdasan bahasa dan logika matematika), afektif (sikap dan nilai yang mencakup kecerdasan emosional, antarpribadi dan intrapribadi), dan psikomotor (kecepatan dan kualitas bertindak/bergerak). Jadi, aspek kemampuan penyelesaian masalah matematis, koneksi matematis masuk ke dalam ranah kognitif sedangkan aspek afektif/psikologis mencakup minat belajar, motivasi belajar, percaya diri, self-efficacy, self-esteem dan lain sebagainya. 
Menurut Sriyanto (2004) pelajaran matematika di sekolah sering kali menjadi momok yang menakutkan karena siswa menganggap matematika merupakan pelajaran yang sulit. Anggapan tersebut tidak terlepas dari persepsi masyarakat tentang matematika yang menganggap matematika adalah ilmu abstrak, penuh dengan lambang-lambang dan rumusrumus yang membingungkan. Persepsi tentang matematika tersebut muncul dari pengalaman ketika belajar matematika di sekolah.

Hasil pengamatan tersebut diperkuat dengan hasil penelitian yang dilakukan oleh Sukoco dan Mahmudi (2016) yang menyatakan bahwa siswa masih takut ketika guru menyuruh mereka kedepan untuk menjelaskan jawaban yang mereka peroleh, siswa takut jika jawaban yang mereka dapatkan salah, dan siswa juga takut jika mereka tidak dapat menjelaskan hasil yang mereka miliki dengan baik di depan kelas. Wahyudin (Tamalene, 2010) memberikan gambaran proses belajar mengajar matematika masa kini dalam penelitiannya, bahwa sebagian besar siswa tampak mengikuti proses pembelajaran dengan baik dan mendengarkan setiap penjelasan atau informasi yang disampaikan oleh gurunya, tetapi para siswa terlihat pasif dan takut mengungkapkan pendapat mereka, sehingga yang terjadi adalah guru asyik sendiri menjelaskan apa yang telah disiapkannya, di lain pihak siswa juga asyik sendiri menjadi penerima informasi yang baik. Akibatnya, siswa hanya mengikuti apa yang dikerjakan guru dan mengingat rumus-rumus atau aturan-aturan matematika tanpa mengetahui makna dan pengertiannya.

Menurut hasil penelitian Ruspiani (2000), yang menunjukkan nilai rata-rata kemampuan koneksi matematis siswa sekolah menengah masih rendah yaitu kurang dari 60 pada skor 100 (22,2\% untuk koneksi matematika pada pokok bahasan lain, $44 \%$ untuk koneksi bidang studi lain, dan 67,3\% untuk koneksi matematika pada kehidupan sehari-hari). Begitu pula dengan hasil penelitian Kusuma (Yuniawatika, 2011), yang menyatakan bahwa tingkat kemampuan koneksi matematis siswa SMP masih rendah. Hasil penelitian tersebut menunjukkan bahwa jumlah siswa yang memiliki kemampuan koneksi tinggi masih rendah untuk setiap jenisnya.

Di samping itu, rasa percaya diri dan tingkat keyakinan siswa masih kurang jika diminta guru untuk menyelesaikan soal-soal matematika. Seperti contoh, ketika guru menunjuk salah satu siswa mengerjakan soal di papan tulis, siswa tersebut tidak mau maju ke depan karena takut salah dan kurang yakin pada dirinya sendiri apakah pekerjaannya benar. Hasil pekerjaan beberapa siswa yang ditunjukkan oleh guru kepada peneliti terkesan ragu-ragu dalam menuliskan langkah-langkah penyelesaian padahal konsep awal penyelesaian sudah benar. 
Hal ini menunjukkan dugaan bahwa self-efficacy dan kemampuan koneksi matematis siswa masih rendah.

Oleh karena itu, beberapa siswa kurang mampu menghubungkan konsep-konsep matematis, terbukti pada saat guru memberikan contoh soal di papan tulis, siswa masih harus di bimbing oleh guru dalam mengkaitkan konsep awal dengan konsep baru. Hasil ulangan yang diperlihatkan oleh guru menunjukkan bahwa beberapa langkah penyelesaian siswa tidak selesai sampai pada tahap akhir penyelesaian soal (hanya berhenti pada beberapa langkah saja). Dari beberapa uraian di atas, maka kemampuan koneksi matematis serta self-efficacy sangat berhubungan dan berperan penting dalam pembelajaran karena diantara ketiga aspek tersebut saling berhubungan dan pada akhirnya bermuara pada prestasi belajar matematika siswa.

Beberapa fakta lain adalah metode pembelajaran yang dilakukan masih didominasi oleh guru. Siswa hanya sebagai objek pembelajaran, dimana dalam pelaksanaannya siswa hanya mendengarkan penjelasan guru ataupun mencatat apa yang ada di papan tulis. Frekuensi pemberian soal-soal matematika dari guru yang bersifat kontekstual (berkaitan dengan realita kehidupan sehari-hari) masih sangat kurang. Soal-soal yang diberikan guru pun masih sebatas hanya soal-soal perhitungan rutin yang masih kurang memberikan kesempatan kepada siswa untuk menganalisis permasalahan hidup sehari-hari. Kecenderungan pembelajaran matematika yang terjadi di kelas masih kurang dalam hal mengamati permasalahan yang ada di lingkungan sekitarnya sehingga siswa kurang terlatih untuk menyelesaikan permasalahan hidup sehari-hari yang berhubungan dengan konsep matematika.

Mengatasi kesenjangan antara harapan dan kenyataan di atas, maka diperlukan strategi pembelajaran yang sesuai untuk meningkatkan prestasi belajar matematika, melatih kemampuan koneksi dapat melibatkan siswa secara aktif dalam pembelajaran. Menurut Johnson (Isjoni, 2009) di dalam model pembelajaran kooperatif terdapat beberapa tipe atau teknik yang dapat dipilih, diantaranya yaitu : Student Team Achievement Division (STAD), Team Assisted Individualization (TAI), Team Games Tounament (TGT), Jigsaw, Group Investigation (GI), Rotating Trio Exchange (RTE), Numbered Heads Together, Two Stay Two Stray.

Model pembelajaran kooperatif tipe Rotating Trio Exchange (RTE) merupakan cara yang efektif untuk mengubah pola belajar dalam kelas. Model ini berpusat pada siswa sehingga menuntun siswa untuk berinteraksi, berekspresi, mengeluarkan pendapat sendiri, menemukan ilmu dan mengungkapkannya kepada teman. Cara ini menurut Siberman (2009) 
dalam bukunya Active Learning sangat sesuai dengan siswa zaman sekarang yang cenderung lebih sering bosan dengan hal-hal yang monoton.

Pelaksanaan model pembelajaran Rotating Trio Exchange (RTE) adalah dengan cara membagi kelas menjadi beberapa kelompok yang terdiri dari 3 siswa. Setiap kelompok yang beranggotakan 3 orang (trio) ini akan diberikan pertanyaan yang sama untuk didiskusikan. Kemudian setiap anggota akan diberikan nomor, misalnya 1, 2, dan 3 untuk mempermudah dilakukannya rotasi. Instruksikan nomor 3 berpindah searah jarum jam dan nomor 1 sebaliknya, sedangkan nomor 2 tetap ditempat. Ini akan mengakibatkan munculnya trio baru dengan anggota yang berbeda dari kelompok pertama. Guru akan memberikan kepada trio baru tersebut pertanyaan baru dengan tingkat kesulitan yang berbeda untuk didiskusikan dalam menyatukan konsep.

Proses rotasi yang dilakukan oleh siswa memerlukan rasa tanggung jawab, tekun dan ulet dalam berdiskusi dengan teman diskusi yang berbeda untuk mendapatkan keberhasilan yang bersama, dimana dapat meningkatkan kemampuan koneksi matematis dan self-eficacy siswa. Dalam proses pembelajaran kooperatif Rotating Trio Exchange (RTE) menekankan pada kesuksesan kelompok, siswa belajar bersama dan memiliki tanggung jawab bersama terhadap kemajuan kelompoknya. Sesuai dengan pendapat Johnson et. al (Trianto, 2010) terdapat lima unsur penting dalam pembelajaran kooperatif, yaitu : (1) saling ketergantungan yang bersifat positif antara siswa, (2) interaksi siswa yang semakin meningkat, (3) tanggung jawab individual, (4) keterampilan interpersonal dan kelompok kecil, (5) proses kelompok.

Partisipasi aktif menjadi tempat bagi siswa dalam mengembangkan kemampuan koneksi matematis dan self-efficacy, sehingga proses penerimaan atau pemahaman materi pelajaran benar-benar merupakan hasil interaktif aktif antar siswa itu sendiri. Dengan demikian, tipe Rotating Trio Exchange (RTE) ini diharapkan dapat meningkatkan kemampuan koneksi matematis dan self-efficacy siswa.

Berdasarkan latar belakang masalah maka permasalah yang akan dikaji dalam penelitian ini adalah sebagai berikut: (1) Apakah peningkatan kemampuan koneksi matematis siswa yang memperoleh pembelajaran dengan model pembelajaran kooperatif tipe Rotating Trio Exchange (RTE) lebih baik dibandingkan siswa yang memperoleh pembelajaran matematika secara konvensional?; (2) Apakah peningkatan self-efficacy siswa yang memperoleh pembelajaran dengan model pembelajaran kooperatif RTE lebih baik dibandingkan siswa yang memperoleh pembelajaran matematika secara konvensional? 


\section{METODE}

Pendekatan yang digunakan dalam penelitian ini adalah pendekatan kuantitatif. Penelitian ini bertujuan untuk mencari pengaruh perlakuan tertentu terhadap yang lain dalam kondisi yang terkendalikan, yaitu mengetahui kemampuan koneksi matematis dan selfefficacy siswa setelah mendapatkan pembelajaran dengan model kooperatif Rotating Trio Exchange (RTE). Desain yang digunakan dalam penelitian ini adalah desain eksperimen.

Desain penelitian dari kedua variabel tersebut ialah sebagai berikut :

Kelas Pre tes Perlakuan Post tes

$\begin{array}{llll}\text { Eksperimen } & \mathrm{O}_{1} & \mathrm{X} & \mathrm{O}_{2}\end{array}$

Kontrol $\quad O_{1} \quad O_{2}$

Keterangan :

$O_{1}=$ Hasil tes awal peserta didik sebelum diberikan perlakuan.

$\mathrm{O}_{2}=$ Hasil tes awal peserta didik setelah diberikan perlakuan.

$\mathrm{X}=$ Pembelajaran matematika menggunakan model pembelajaran kooperatif tipe Rotating

Trio Exchange (RTE)

Populasi penelitian ini adalah siswa kelas VII SMP PGRI Dewantara. Sampel dari penelitian ini diambil dua kelas secara acak dari seluruh kelas VII di SMP PGRI Dewantara, yaitu satu kelas sebagai kelas eksperimen yaitu kelas yang menggunakan model pembelajaran kooperatif tipe Rotating Trio Exchange (RTE) dan satu kelas sebagai kelas kontrol yaitu kelas yang menggunakan pembelajaran konvensional.

Instrumen tes yang digunakan untuk mengukur kemampuan koneksi matematis siswa adalah soal-soal yang berbentuk uraian. Soal tersebut terlebih dahulu dikembangkan berdasarkan indikator kemampuan koneksi matematis kemudian dikonsultasikan kepada validator yang lebih ahli dalam mengembangkan kemampuan koneksi matematis, yaitu dosen prodi pendidikan matematika STKIP BBG, dosen prodi pendidikan matematika FKIP Unsyiah, guru SMP PGRI Dewantara serta teman sejawat yang memiliki keahlian dalam bidang matematika. Selanjutnya dilakukan ujicoba untuk mengetahui tingkat validitas, reliabilitas, tingkat kesukaran dan daya pembeda.

Untuk mendapatkan validitas, instrumen angket self-efficacy tersebut terlebih dahulu dikembangkan berdasarkan indikator yang akan diukur. Kemudian angket tersebut dikonsultasikan kepada validator yang lebih ahli dalam memahami self-efficacy siswa. Setelah direvisi maka angket self-efficacy akan diberikan kepada siswa. Butir dari self-efficacy juga diuji validitas dan reliabilitas dari setiap pernyataan. 
Data yang berasal dari hasil tes kemampuan koneksi matematis dan self-efficacy siswa melalui model pembelajaran tipe Rotating Trio Exchange (RTE) dan pembelajaran secara konvensional, dianalisis dengan cara membandingkan skor pretest dan postest yang berasal dari kemampuan koneksi matematis dan self-efficacy. Menguji normalitas data dan gain dengan menggunakan uji statistik Kolmogorov-smirnov. Menguji homogenitas varians skor dan gain untuk melihat homogenitas atau kesamaan beberapa bagian sample yaitu seragam tidaknya varians sampel-sampel yang diambil dari populasi yang sama. Uji homogenitas yang digunakan adalah uji Levene's Test dengan kriteria pengujian adalah terima $\mathrm{H}_{\mathrm{o}}$ apabila sig. Based Mean > taraf signifikansi $(\alpha=0,05)$. Setelah data memenuhi syarat normalitas dan homogenitas maka selanjutnya dilakukan uji perbedaan rata-rata skor dan n-gain dengan menggunakan uji Independent Sample t-test.

\section{HASIL DAN PEMBAHASAN}

Hasil tes kemampuan koneksi matematis dalam penelitian ini merupakan hasil pengolahan skor pretest dan postest yang diberikan kepada dua kelas VII di SMP PGRI Dewantara. Skor pretest dan postest diolah dan dikaji sesuai dengan pengolahan data yang telah dirancang dalam metode penelitian. Semua ini dilakukan dengan tujuan untuk membuktikan kebenaran hipotesis dalam menganalisis penyebab dan hal-hal yang terkait. Berikut disajikan data deskriptif pada tabel 1

Tabel 1. Data Deskriptif Kemampuan Koneksi Matematis Siswa

\begin{tabular}{|c|c|c|c|c|c|c|c|c|c|c|c|}
\hline \multirow{2}{*}{$\begin{array}{c}\text { Kemampuan } \\
\text { Koneksi } \\
\text { Matematis } \\
\end{array}$} & \multirow{2}{*}{ Tes } & \multicolumn{5}{|c|}{ Kelas Eksperimen } & \multicolumn{5}{|c|}{ Kelas Kontrol } \\
\hline & & $\mathbf{N}$ & Xmax & Xmin & $(\bar{x})$ & $S$ & $\mathbf{N}$ & Xmaks & Xmin & $(\bar{x})$ & $S$ \\
\hline \multirow{3}{*}{$\begin{array}{l}\text { Koneksi } \\
\text { matematis }\end{array}$} & Pretes & 30 & 50 & 5 & 21,87 & 11,26 & 30 & 60 & 5 & 32,10 & 19,09 \\
\hline & $\begin{array}{l}\text { Poste } \\
\mathrm{s}\end{array}$ & 30 & 100 & 20 & 67,10 & 23,02 & 30 & 92 & 15 & 60,60 & 18,42 \\
\hline & Gain & & & & 0,32 & 0,214 & & & & 0,21 & 0,176 \\
\hline
\end{tabular}

Dari hasil analisis terhadap skor rata-rata pretes kemampuan koneksi kedua kelas, diperoleh skor rata-rata sebesar 21,87 dengan standar deviasi sebesar 11,26 untuk kelas eksperimen atau kelas yang akan memperoleh pembelajaran dengan menggunakan model pembelajaran tipe RTE. Sedangkan pada kelas kontrol atau kelas yang akan memperoleh pembelajaran konvensional diperoleh skor rata-rata 32,10 dengan standar deviasi sebesar 19,09. Hal ini menunjukkan bahwa rata-rata pretest kedua kelas tidak jauh berbeda secara signifikan. Dapat dilihat juga bahwa nilai standar deviasi kelas kelas kontol lebih besar 
daripada kelas eksperrimen, ini menunjukkan bahwa kemampuan koneksi matematis kelas kontrol lebih menyebar daripada kelas eksperimen.

Hasil analisis terhadap skor rata-rata posttest pada kelas eksperimen dan kelas kontrol, dapat dilihat bahwa kemampuan koneksi matematis kelas eksperimen lebih baik daripada kelas kontrol. Skor rata-rata postest kemampuan koneksi matematis kelas eksperimen (kelas yang memperoleh pembelajaran dengan pendekatan RTE) adalah 67,10 (dari skor ideal 100) dengan standar deviasi 23,02. Sedangkan pada kelas kontrol rata-ratanya adalah 60,60 (dari skor ideal 100) dengan standar deviasi 18,42. Hal ini sejalan dengan penelitian Purwati (2013), yang menyatakan bahwa analisis data posttest pencapaian indikator pemahaman konsep matematis siswa, terlihat bahwa rata-rata pencapaian indikator pemahaman konsep matematis siswa kelas yang mengikuti pembelajaran RTE lebih tinggi daripada rata-rata pencapaian indikator pemahaman konsep matematis siswa kelas yang mengikuti pembelajaran konvensional. Ini menunjukkan bahwa pembelajaran dengan model pembelajaran tipe RTE dapat meningkatkan kemampuan koneksi matematis siswa dibandingkan dengan pendekatan konvensional.

Berdasarkan hasil penelitian yang telah dilakukan, diperoleh analisis data sebagai berikut:

Tabel 2. Uji Perbedaan Rata-rata N-Gain Koneksi Matematika

\begin{tabular}{cccc}
\hline Kelas & Sig. (2-tailed) & Sig. (1-tailed) & Kesimpulan \\
\cline { 1 - 1 } Eksperimen & 0,071 & 0,035 & Tolak $\mathrm{H}_{0}$ \\
\cline { 1 - 2 } Kontrol & 0 & 0
\end{tabular}

Dari Tabel 2 di atas terlihat bahwa N-Gain koneksi matematis dengan nilai Sig. (2tailed) $=0,035$. Karena melakukan uji hipotesis satu sisi (1-tailed) maka nilai sig. (2-tailed) harus dibagi dua menjadi nilai Sig. (1-tailed). Karena nilai Sig. (1-tailed) < taraf Signifikansi $(\alpha=0,05)$, maka $H_{o}$ ditolak. Sehingga dapat disimpulkan bahwa rata-rata gain ternormalisasi koneksi matematika kelas eksperimen lebih baik daripada rata-rata gain ternormalisasi kelas kontrol.

Hal ini menunjukkan bahwa peningkatan kemampuan koneksi matematis kelas eksperimen lebih tinggi daripada peningkatan koneksi matematis kelas kontrol. Tingginya peningkatan kemampuan koneksi matematis pada kelas eksperimen disebabkan karena pada kelas eksperimen aktivitas siswa lebih ditekankan untuk mengkonstruksi pengetahuannya sendiri sehingga siswa lebih termotivasi untuk belajar dan dapat meningkatkan kemampuan 
berpikir siswa. Hasil penelitian ini sesuai dengan pendapat Hasnawati (2006), yang menyatakan bahwa kegiatan mengkonstruksi atau membangun sendiri pengetahuannya dapat membuat siswa terlatih untuk bernalar atau berpikir secara kritis melalui kegiatan menemukan (inquiry), kebebasan bertanya (questioning), masyarakat belajar (learning community) yang dapat melatih siswa untuk bekerjasama, berbagi ide, berbagi pengalaman, pengetahuan, saling berkomunikasi sehingga terjadi interaksi yang positif antar siswa dan pada akhirnya siswa terlibat secara aktif belajar bersama-sama.

Rata-rata gain ternormalisasi merupakan gambaran peningkatan self-efficacy setelah mengikuti pembelajaran, baik yang mengikuti pembelajaran dengan model Rotating Trio Exchange (RTE) (kelas eksperimen) maupun yang mengikuti pembelajaran dengan model konvensional (kelas kontrol). Berikut ini disajikan analisis statistik deskriptif data $\mathrm{N}$-gain secara keseluruhan antara kelas eksperimen dan kelas kontrol.

Tabel 3. Analisis Statistik Deskriptif Data N-Gain self-efficacy Siswa

\begin{tabular}{lcccccc}
\hline & n & Min & Max & Mean & $\begin{array}{c}\text { Std. } \\
\text { Deviation }\end{array}$ & $\begin{array}{c}\text { Varianc } \\
\text { e }\end{array}$ \\
\hline Postes kelas eksperimen & 30 & 0 & 1 & 0,50 & 0,212 & 0,045 \\
\hline Postes kelas kontrol & 30 & 0 & 1 & 0,42 & 0,237 & 0,056 \\
\hline
\end{tabular}

Berdasarkan tabel 3 dapat diuraikan deskripsi rata-rata N-gain self-efficacy siswa yang memperoleh pembelajaran model Rotating Trio Exchange (RTE) (kelas eksperimen) lebih tinggi daripada siswa yang memperoleh pembelajaran konvensional (kelas kontrol) yaitu 0,50 dan 0,42. Jika mengacu pada kriteria $\mathrm{N}$-gain, maka rata-rata $\mathrm{N}$-gain kelas eksperimen dan $\mathrm{N}$ gain kelas kontrol sama-sama tergolong sedang. Hasil ini menunjukkan bahwa secara umum peningkatan self-efficacy siswa yang memperoleh pembelajaran model Rotating Trio Exchange (RTE) lebih baik dibandingkan siswa yang memperoleh pembelajaran dengan model konvensional. Namun demikian, untuk membuktikan apakah peningkatan self-efficacy siswa berbeda secara signifikan maka diperlukan uji statistik lebih lanjut.

Hasil analisis nilai rata-rata pretest self-efficacy siswa, diperoleh skor rata-rata sebesar 25,60 dengan standar deviasi sebesar 3,719 untuk kelas eksperimen (kelas yang akan memperoleh pembelajaran dengan menggunakan model pembelajaran tipe RTE). Sedangkan pada kelas kontrol atau kelas yang akan memperoleh pembelajaran konvensional diperoleh skor rata-rata 21,90 dengan standar deviasi sebesar 5,215. Hal ini menunjukkan bahwa ratarata pretest kedua kelas tidak jauh berbeda secara signifikan. Dapat dilihat juga bahwa nilai 
standar deviasi kelas kontrol lebih besar daripada kelas eksperimen, ini menunjukkan bahwa self-efficacy kelas kontrol lebih menyebar daripada kelas eksperimen.

Berdasarkan hasil analisis terhadap skor rata-rata posttest self-efficacy pada kelas eksperimen dan kelas kontrol, dapat dilihat bahwa self-efficacy kelas eksperimen lebih baik daripada kelas kontrol. Skor rata-rata posttest self-efficacy kelas eksperimen (kelas yang memperoleh pembelajaran dengan model pembelajaran tipe RTE) adalah 60,67 (dari skor ideal 100) dengan standar deviasi 22,3. Sedangkan pada kelas kontrol rata-ratanya adalah 54,67 (dari skor ideal 100) dengan standar deviasi 17,6133. Karena rata-rata nilai posttest kelas eksperimen lebih tinggi daripada kelas kontrol menujukkan bahwa pembelajaran dengan model pembelajaran tipe RTE dapat meningkatkan self-efficacy siswa dibandingkan dengan pendekatan konvensional.

Hasil pembahasan di atas, memperlihatkan bahwa siswa yang memperoleh pembelajaran dengan model pembelajaran tipe Rotating Trio Exchange (RTE) mengalami peningkatan kemampuan koneksi dan self-efficacy siswa lebih baik dibandingkan dengan siswa yang memperoleh pembelajaran dengan pendekatan konvensional. Hal ini terjadi karena siswa sangat semangat mengikuti proses pembelajaran dengan model pembelajaran tipe Rotating Trio Exchange (RTE) sehingga pembelajaran semakin bermakna. Hal senada juga diungkapkan oleh Dyatma (2014), menyimpulkan bahwa siswa sangat antusias dan senang mengikuti pembelajaran dengan model pembelajaran tipe Rotating Trio Exchange (RTE) serta tes hasil belajar siswa menjadi semakin meningkat. Jadi, dari penelitian terdahulu terlihat jelas bahwa model pembelajaran tipe Rotating Trio Exchange (RTE) membawa dampak positif terhadap hasil belajar siswa..

Peningkatan hasil kemampuan belajar juga didukung oleh sikap siswa yang secara umum memiliki respon positif terhadap pembelajaran matematika. Secara keseluruhan siswa juga beranggapan bahwa pembelajaran dengan model pembelajaran tipe Rotating Trio Exchange (RTE) lebih membantu mereka memahami materi matematika yang sedang mereka pelajari. Hal ini sesuai dengan penelitian Permana (2007), menyimpulkan bahwa siswa bersikap positif terhadap pelajaran matematika, pembelajaran berbasis masalah, dan terhadap bentuk bentuk soal penalaran dan koneksi matematis. Ini terlihat dari siswa menunjukkan rasa senang, antusias dan bersemangat pada waktu proses pembelajaran berlangsung, serta tidak takut mengeluarkan pendapat. 


\section{SIMPULAN}

Berdasarkan hasil penelitian dan pembahasan yang telah dikemukakan pada bagian terdahulu dapat diambil beberapa kesimpulan yang berkaitan dengan peningkatan koneksi matematis siswa dan self-efficacy siswa VII di SMP PGRI Dewantara melalui pembelajaran dengan model pembelajaran tipe Rotating Trio Exchange (RTE). Adapun kesimpulan tersebut diatas sebagai berikut: (1) Peningkatan kemampuan koneksi matematis siswa yang memperoleh pembelajaran dengan model pembelajaran tipe Rotating Trio Exchange (RTE) lebih baik dibandingkan dengan kemampuan koneksi matematis siswa yang memperoleh pembelajaran konvensional. (2) Peningkatan kemampuan self-efficacy siswa yang memperoleh pembelajaran dengan model pembelajaran tipe Rotating Trio Exchange (RTE) lebih baik dibandingkan dengan kemampuan self-efficacy siswa yang memperoleh pembelajaran konvensional.

\section{DAFTAR PUSTAKA}

Bandura, A. (1997). Self-Efficacy: the exercise of control. New York: W. H. Freeman /Times Books.

Dyatma. (2014). Pengaruh Strategi Pembelajaran Rotating Trio Exchange (RTE) terhadap Hasil Belajar Matematika. Jurnal Mimbar PGSD Universitas Pendidikan Ganesha Jurusan PGSD.

Hasnawati. (2006). Pendekatan Contextual Teaching Learning Hubungannya dengan Evaluasi Pembelajaran. Jurnal Pendidikan, 3(1)

Isjoni. (2012). Pembelajaran Kooperatif Meningkatkan Kecerdasan Komunikasi Antar Peserta Didik. Yogyakarta: Pustaka Pelajar.

National Council of Teachers of Mathematics. (2000). Principles and Standarts for School Mathematics. Reston, VA: NCTM.

Permana, Y, dan Sumarno, U. (2007). Mengembangkan Kemampuan Penalaran dan Koneksi Matematik Siswa SMA Melalui Pembelajaran Berbasis Masalah. Jurnal EDUCATIONIST, 1(2), 116-123.

Peraturan Menteri Pendidikan Nasional Nomor 20 Tahun 2007 tentang Standar Penilaian Pendidikan, Jakarta: Direktorat Jenderal Manajemen Pendidikan Dasar dan Menengah.

Purwanti, Eka. (2013). Pengaruh Penerapan Model Pembelajaran Rotating Trio Exchange Terhadap Pemahaman Konsep Matematis Siswa. Pendidikan Matematika, Universitas Lampung

Ruspiani. (2000). Kemampuan Siswa Dalam Melakukan Koneksi Matematika. Tesis Pasca Sarjana Universitas Pendidikan Indonesia, tidak diterbitkan. Bandung: PPs UPI.

Silberman. (2009). Active Learning 101 Strategi Pembelajaran Aktif. Yogyakarta: Pustaka Insan Madani.

Sriyanto. (2004). Momok Itu Bernama Matematika. Basis, Edisi Juli-Agustus 2004.[Online] Sukoco, H., \& Mahmudi, A. (2016). Pengaruh Pendekatan Brain-Based Learning terhadap Kemampuan Komunikasi Matematis dan Self-Efficacy Siswa SMA, Jurnal Pendidikan Matematika, 11(1), 11-24 
Tamalene, Hanisa. (2010). Pembelajaran Matematika dengan Model CORE Melalui Pendekatan Keterampilan Metakognitif Untuk Meningkatkan Kemampuan Penalaran Matematis Siswa Sekolah Menengah Pertama. Tesis Pasca Sarjana Universitas Pendidikan Indonesia, tidak diterbitkan. Bandung: SPs UPI.

Uyanto. (2009). Pedoman Analisis Data dengan SPSS. Yogyakarta: Graha Ilmu.

Yuniawatika. (2011). Penerapan Pembelajaran Matematika dengan Strategi React Untuk Meningkatkan Kemampuan Koneksi dan Representasi Matematik Siswa Sekolah Dasar (Studi Kuasi Eksperimen di Kelas V Sekolah Dasar Kota Cimahi). ISSN 1412-565X. Edisi Khusus No. 1, Agustus 2011. 